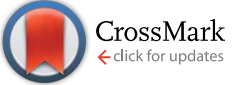

Cite this: J. Mater. Chem. A, 2016, 4, 13837

Received 26th May 2016

Accepted 9th August 2016

DOI: $10.1039 / c 6 t a 04363 a$

www.rsc.org/MaterialsA

\title{
Effects of interfacial layers on the photoelectrochemical properties of tantalum nitride photoanodes for solar water splitting $†$
}

\author{
Chizhong Wang, ${ }^{a}$ Takashi Hisatomi, ${ }^{\text {ab }}$ Tsutomu Minegishi, ${ }^{\text {abc }}$ Mamiko Nakabayashi, ${ }^{d}$ \\ Naoya Shibata, d Masao Katayama ${ }^{a b}$ and Kazunari Domen ${ }^{\star a b}$
}

\begin{abstract}
This work describes the effects of interlayers on the structural, crystalline and photoelectrochemical properties of $\mathrm{Ta}_{3} \mathrm{~N}_{5}$ photoanodes. $\mathrm{Nb}_{4} \mathrm{~N}_{5}$ interlayers with different thicknesses are formed between $\mathrm{Ta}_{3} \mathrm{~N}_{5}$ films and $\mathrm{Ta}$ back substrates using a thin film transfer method. Zone-axis images and electron diffraction patterns of cross-sections of the resulting $\mathrm{Ta}_{3} \mathrm{~N}_{5} / \mathrm{Nb}_{4} \mathrm{~N}_{5} / \mathrm{Ta} / \mathrm{Ti}$ electrodes acquired by transmission electron microscopy evidence the formation of a $200 \mathrm{~nm}$ thick oriented $\mathrm{Ta}_{3} \mathrm{~N}_{5}$ grain layer in the vicinity of the interlayer. This oriented $\mathrm{Ta}_{3} \mathrm{~N}_{5}$ layer promotes electron transport throughout the $\mathrm{Ta}_{3} \mathrm{~N}_{5}$ film. As a result, a $\mathrm{Ta}_{3} \mathrm{~N}_{5}$ photoanode incorporating a $\mathrm{Nb}_{4} \mathrm{~N}_{5}$ interlayer exhibits a higher photocurrent during the oxygen evolution reaction. These results obtained using the $\mathrm{Ta}_{3} \mathrm{~N}_{5} /$ interlayer/ substrate configuration elucidate the key role played by the buffer layer in achieving efficient water splitting with $\mathrm{Ta}_{3} \mathrm{~N}_{5}$ photoelectrodes.
\end{abstract}

\section{Introduction}

Photoelectrochemical (PEC) water splitting is a process used to store solar light energy via the formation of hydrogen. ${ }^{1-3} \mathrm{Ta}_{3} \mathrm{~N}_{5}$, an n-type semiconductor, has been widely applied as a photoanode for the PEC oxygen evolution reaction (OER). With a bandgap of $2.1 \mathrm{eV}, \mathrm{Ta}_{3} \mathrm{~N}_{5}$ absorbs visible light up to $600 \mathrm{~nm}$ (ref. 4) and can potentially yield a maximum photocurrent of $12.5 \mathrm{~mA} \mathrm{~cm}^{-2}$ under irradiation by sunlight (AM 1.5G).

Photoanodes are typically prepared as either thin films, ${ }^{5}$ nanostructures (such as nanorods and nanotubes) $)^{6-8}$ or particulate layers. ${ }^{9,10}$ In addition, doping, surface modification and other strategies have been applied to achieve high photocurrents and negative onset potentials during PEC water oxidation. ${ }^{11-16}$ Theoretical studies have indicated that $\mathrm{Ta}_{3} \mathrm{~N}_{5}$ is an anisotropic semiconductor material in which holes are heavier than electrons, ${ }^{17}$ resulting in low mobility of the minority charge carriers (i.e., the holes), while the porosity of the $\mathrm{Ta}_{3} \mathrm{~N}_{5}$

${ }^{a}$ Department of Chemical System Engineering, School of Engineering, The University of Tokyo, 7-3-1 Hongo, Bunkyo-ku, 113-8656 Tokyo, Japan. E-mail: domen@chemsys.t. u-tokyo.ac.jp; Fax: +81 35841 8838; Tel: +81 358411148

${ }^{b}$ Japan Technological Research Association of Artificial Photosynthetic Chemical Process (ARPChem), 2-11-9 Iwamotocho, Chiyoda-ku, 101-0032 Tokyo, Japan

'Japan Science and Technology Agency/Precursory Research for Embryonic Science and Technology (JST/PRESTO), Kawaguchi Center Building, 4-1-8, Honcho, Kawaguchi-shi, 332-0012 Saitama, Japan

${ }^{d}$ Institute of Engineering Innovation, The University of Tokyo, 2-11-16 Yayoi, Bunkyoku, 113-8656 Tokyo, Japan

$\dagger$ Electronic supplementary information (ESI) available. See DOI: 10.1039/c6ta04363a layer in a $\mathrm{Ta}_{3} \mathrm{~N}_{5}$ photoanode is believed to limit the bulk transport of the majority charge carriers (electrons). ${ }^{18}$ Controlling both the structure and crystallinity of $\mathrm{Ta}_{3} \mathrm{~N}_{5}$ films is a critical aspect of improving the PEC performance of this material because these parameters significantly affect the charge separation efficiency as well as the light absorption of the $\mathrm{Ta}_{3} \mathrm{~N}_{5} \cdot{ }^{17-20}$

Studies on the growth of GaN films suggest that a GaN or AlN buffer layer will generate high crystalline quality in the upper GaN film, ${ }^{21,22}$ and a similar effect is anticipated in the case of $\mathrm{Ta}_{3} \mathrm{~N}_{5}$ film growth. In order to fabricate semiconductor/ conductor configurations for use as photoelectrodes, $\mathrm{Ta}_{3} \mathrm{~N}_{5}$ films are generally grown on conductive substrates, such as metallic Ta foils or $\mathrm{Pt}^{23}$ by nitridation under a flow of $\mathrm{NH}_{3}$ gas and at high temperatures $\left(800-1000{ }^{\circ} \mathrm{C}\right)$. To date, $\mathrm{Ta}_{3} \mathrm{~N}_{5}$ photoanodes with state-of-the-art PEC performance have been fabricated on Ta foil substrates. ${ }^{11,24}$ However, an impurity interlayer consisting of $\mathrm{TaN}_{x}$ phases is inevitably formed between the $\mathrm{Ta}_{3} \mathrm{~N}_{5}$ film (or nanorods and nanotubes) and the underlying Ta foil during the nitridation process. ${ }^{6,20}$ The effects of this interlayer on electron transport in the $\mathrm{Ta}_{3} \mathrm{~N}_{5}$ film and at the $\mathrm{Ta}_{3} \mathrm{~N}_{5} / \mathrm{TaN}_{x}$ interface are expected to alter the PEC performance of $\mathrm{Ta}_{3} \mathrm{~N}_{5}$ photoanodes.

In the present work, the effects of interlayers on the growth of $\mathrm{Ta}_{3} \mathrm{~N}_{5}$ films and on the PEC performance of $\mathrm{Ta}_{3} \mathrm{~N}_{5}$ photoanodes were assessed by introducing a niobium nitride $\left(\mathrm{NbN}_{x}\right)$ layer at the interface between the $\mathrm{Ta}_{3} \mathrm{~N}_{5}$ film and the conductive substrate by a thin film transfer technique. ${ }^{25}$ Inert $\mathrm{Si}$ wafers were used as synthesis platforms for the formation of the $\mathrm{NbN}_{x}$ and $\mathrm{Ta}_{3} \mathrm{~N}_{5}$ bilayer films. After the film transfer process, the $\mathrm{NbN}_{x}$ surface layer acted as a back contact to conduct photogenerated electrons 
from the $\mathrm{Ta}_{3} \mathrm{~N}_{5}$ film to the back conductive layer, and the introduction of a $\mathrm{NbN}_{x}$ interlayer was found to enhance the photocurrent of the $\mathrm{Ta}_{3} \mathrm{~N}_{5}$ photoanodes. The growth mechanism of the $\mathrm{Ta}_{3} \mathrm{~N}_{5}$ films in the presence of the $\mathrm{NbN}_{x}$ layer and the effects of the interlayer on the structural, crystalline and PEC properties of the $\mathrm{Ta}_{3} \mathrm{~N}_{5}$ films are discussed based on the results of this study.

\section{Experimental section}

\section{Sample preparation}

$A \mathrm{NbN}_{x}$ layer was introduced as an interlayer between $\mathrm{Ta}_{3} \mathrm{~N}_{5}$ and a conductive substrate using a film transfer process, as depicted in Fig. 1. The sections of a single-crystal Si (100) substrate $(1 \times$ $1 \mathrm{~cm}$, Nilaco) were cleaned by sequential ultrasonic irradiation over $10 \mathrm{~min}$ each in acetone, isopropanol and Milli-Q water $(18.2 \mathrm{~m} \Omega \mathrm{cm})$. Ta and $\mathrm{Nb}$ films with the desired thicknesses were sequentially deposited on the $\mathrm{Si}$ substrates by radio frequency (RF) magnetron sputtering (ULVAC, MNS-2000-RFG3) and the resulting multi-layered films were oxidized in a muffle furnace at $700{ }^{\circ} \mathrm{C}$ for $2 \mathrm{~h}$ with a temperature ramp rate of $15^{\circ} \mathrm{C}$ $\min ^{-1}$. The $\mathrm{Nb}_{2} \mathrm{O}_{5} / \mathrm{Ta}_{2} \mathrm{O}_{5} / \mathrm{Si}$ samples fabricated in this manner were subsequently moved to a tube furnace and nitrided in a flow of $\mathrm{NH}_{3}$ gas $(100 \mathrm{sccm})$ at $900{ }^{\circ} \mathrm{C}$ for $2 \mathrm{~h}$ with a temperature ramp rate of $20{ }^{\circ} \mathrm{C} \mathrm{min}^{-1}$, forming a nitride bilayer on the $\mathrm{Si}$ substrates. To transfer these nitride films onto a conductive substrate, metallic Ta (150 $\mathrm{nm})$ and Ti (approximately $5 \mu \mathrm{m}$ ) layers were sequentially deposited on the $\mathrm{NbN}_{x} / \mathrm{Ta}_{3} \mathrm{~N}_{5} / \mathrm{Si}$ sample by RF magnetron sputtering, serving as the contact and conductive layers, respectively. Because the physical contact between the $\mathrm{Ta}_{3} \mathrm{~N}_{5}$ film and the Si substrate was weakened by the strain imparted upon adding the metallic $\mathrm{Ta} / \mathrm{Ti}$ layers, the $\mathrm{Ti} / \mathrm{Ta} / \mathrm{NbN}_{x} / \mathrm{Ta}_{3} \mathrm{~N}_{5}$ films were readily peeled away from the underlying Si substrate using carbon tape supported with glass plates. For comparison purposes, a $\mathrm{Ta}_{3} \mathrm{~N}_{5} / \mathrm{Ta} / \mathrm{Ti}$ film without a $\mathrm{NbN}_{x}$ interlayer was synthesized in the same manner. The electrode areas exposed to the electrolyte solution were approximately $0.2 \mathrm{~cm}^{2}$. Each of the $\mathrm{Ta}_{3} \mathrm{~N}_{5}$ films used in this work was $630 \mathrm{~nm}$ thick, while the thickness of the $\mathrm{NbN}_{x}$ layer varied from 50 to $200 \mathrm{~nm}$.

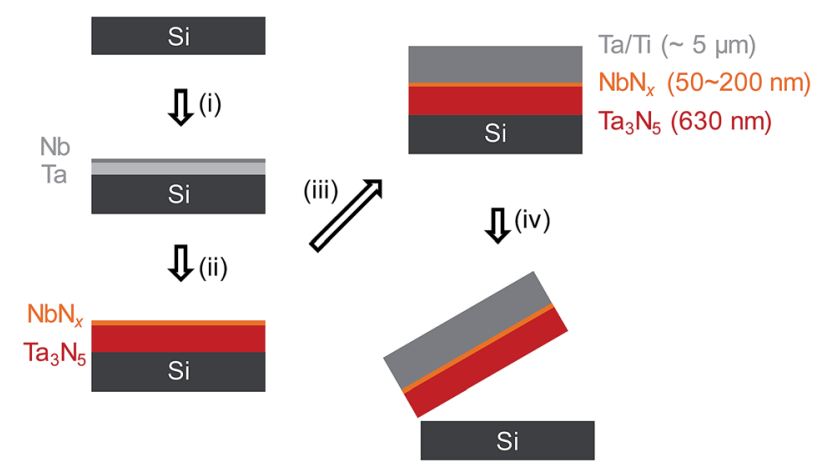

Fig. 1 Schematic diagram of the procedure used to synthesize a $\mathrm{Ta}_{3} \mathrm{~N}_{5}$ film with a $\mathrm{NbN}_{x}$ interlayer. (i) Sputtering of $\mathrm{Ta}$ and $\mathrm{Nb}$ metallic films, (ii) oxidation and nitridation of the $\mathrm{Ta} / \mathrm{Nb}$ films, (iii) sputtering of $\mathrm{Ta} / \mathrm{Ti}$ metallic layers, and (iv) exfoliation of the $\mathrm{NbN}_{x} / \mathrm{Ta}_{3} \mathrm{~N}_{5}$ films from the $\mathrm{Si}$ substrate.

\section{Characterization}

Scanning electron microscopy (SEM, S-4700, Hitachi), transmission electron microscopy and scanning transmission electron microscopy (TEM, STEM, JEM-2800, JEOL) with energy dispersive X-ray fluorescence spectroscopy (EDX, EX-24055JGT, JEOL) were used to characterize the morphologies and structures of the thin films. Samples for cross-sectional SEM and STEM assessments were prepared by ion milling and focused ion beam (FIB) milling, respectively. X-ray diffraction (XRD) patterns were recorded using an X-ray diffractometer (Rigaku Ultima III) with $\mathrm{Cu} \mathrm{K} \alpha$ radiation $(\lambda=0.15405 \mathrm{~nm}, 40 \mathrm{mV}$ and $40 \mathrm{~mA})$. The average crystallite size in the $\mathrm{Ta}_{3} \mathrm{~N}_{5}$ films $(n=3, \pm \sigma)$ was calculated using the Scherrer equation. X-ray fluorescence spectroscopy (XPS, JEOL, JPS-90SX) was performed using Mg Ka radiation ( $8 \mathrm{kV}$ and $10 \mathrm{~mA}$ ), employing the $\mathrm{C} 1 \mathrm{~s}$ peak at $284.8 \mathrm{eV}$ as an internal standard to calibrate the binding energies.

\section{Electrochemical measurement}

Prior to the PEC measurements, each $\mathrm{Ta}_{3} \mathrm{~N}_{5}$ photoelectrode was deposited with a thin layer of $\mathrm{Co}(\mathrm{OH})_{x}$ using an impregnation method. This was accomplished by adding an aqueous $\mathrm{NaOH}$ solution $(50 \mathrm{mM}, 2.5 \mathrm{~mL})$ to an aqueous $\mathrm{Co}\left(\mathrm{NO}_{3}\right)_{2}$ solution (6.3 $\mathrm{mM}, 10 \mathrm{~mL}$ ) and immersing the $\mathrm{Ta}_{3} \mathrm{~N}_{5}$ electrodes in the mixture for $1 \mathrm{~h}$. The PEC properties of the $\mathrm{Ta}_{3} \mathrm{~N}_{5}$ photoanodes were measured using a three-electrode cell with a $\mathrm{Ag} / \mathrm{AgCl}$ reference electrode (in saturated aqueous $\mathrm{KCl}$ ) and $\mathrm{Pt}$ wire as the counter electrode. The $\mathrm{Ag} / \mathrm{AgCl}$ reference potential was converted to the reversible hydrogen electrode (RHE) potential according to the Nernst relationship

$$
E(\mathrm{~V} v s . \mathrm{RHE})=E(\mathrm{~V} v s . \mathrm{Ag} / \mathrm{AgCl})+0.059 \times \mathrm{pH}+0.197
$$

where 0.197 represents the standard potential of the $\mathrm{KCl}-\mathrm{satu}-$ rated $\mathrm{Ag} / \mathrm{AgCl}$ electrode at $25{ }^{\circ} \mathrm{C}$. An aqueous solution of potassium phosphate (KPi, 0.5 M, pH 13) was used as the electrolyte. During these trials, the $\mathrm{Ta}_{3} \mathrm{~N}_{5}$ photoelectrodes were illuminated by using a chopped AM 1.5G solar simulator (San-EI Electric, XES-40S2-CE). Linear-sweep voltammetry (LSV) was employed, scanning from 1.5 to $0 \mathrm{~V} v s$. RHE to evaluate the photocurrent density and onset potential. The photocurrent decay of each $\mathrm{Ta}_{3} \mathrm{~N}_{5}$ photoelectrode was examined in the chronoamperometric mode at $1.0 \mathrm{~V}$ vs. RHE. Evolved gaseous $\mathrm{H}_{2}$ and $\mathrm{O}_{2}$ were simultaneously collected in an air-tight cell and quantified using a micro gas chromatograph (Agilent, 3000A, Micro GC) to calculate the faradaic efficiency.

The incident photon-to-current conversion efficiency (IPCE) was measured under monochromatic irradiation from a Xe lamp (MAX-302, Asahi Spectra) in a 0.5 M KPi electrolyte. The wavelength-dependent IPCEs were calculated using the equation

$$
\mathrm{IPCE}=1240 \times\left(I_{\text {light }}-I_{\text {dark }}\right) /\left(\lambda \times P_{\text {input }}\right) \times 100 \%
$$

where $\lambda(\mathrm{nm})$ is the wavelength of the monochromatic irradiation, $I_{\text {light }}\left(\mathrm{mA} \mathrm{cm}^{-2}\right)$ is the chronoamperometric photocurrent density, $I_{\text {dark }}\left(\mathrm{mA} \mathrm{cm}^{-2}\right)$ is the dark current density and $P_{\text {input }}$ 
( $\mathrm{mW} \mathrm{cm}^{-2}$ ) is the incident photon density as determined by using a Si photodiode detector.

To compare the relative electrochemically active surface areas and roughness factors of different $\mathrm{Ta}_{3} \mathrm{~N}_{5}$ photoelectrodes, the scan-rate dependencies of cyclic voltammograms were estimated according to a previously reported method. ${ }^{26}$ All of the electrodes were tested at different scan rates, varying from 5 to $300 \mathrm{mV} \mathrm{s}^{-1}$, with a capacitive current estimated at $-0.1 \mathrm{~V} v$. $\mathrm{Ag} / \mathrm{AgCl}$. Mott-Schottky measurements were performed in a $0.5 \mathrm{M} \mathrm{KPi}$ electrolyte at a frequency of $1000 \mathrm{~Hz}$ with an AC amplitude of $10 \mathrm{mV}$, using an impedance analyzer (METEK, VersaSTAT3-200). The flat band potential and donor dopant density values of the $\mathrm{Ta}_{3} \mathrm{~N}_{5}$ photoanodes were determined according to the Mott-Schottky relationship

$$
\frac{1}{C_{\mathrm{SC}}^{2}}=\frac{2}{\varepsilon \varepsilon_{0} e N_{\mathrm{D}} r^{2}}\left(E-E_{\mathrm{fb}}-\frac{k T}{e}\right),
$$

where $C_{\mathrm{SC}}\left(\mathrm{F} \mathrm{cm}^{-2}\right)$ is the space-charge capacity per surface area, $\varepsilon_{0}\left(\mathrm{C} \mathrm{V}^{-1} \mathrm{~cm}^{-1}\right)$ is the permittivity of free space, $\varepsilon$ is the dielectric constant of $\mathrm{Ta}_{3} \mathrm{~N}_{5}, N_{\mathrm{D}}\left(\mathrm{cm}^{-3}\right)$ is the donor density, $r$ is the roughness factor of the $\mathrm{Ta}_{3} \mathrm{~N}_{5}$ electrode, $k\left(1.38 \times 10^{-23} \mathrm{~J} \mathrm{~K}^{-1}\right)$ is the Boltzmann constant, $E$ ( $\mathrm{V} v s$. RHE) is the applied potential, and $E_{\mathrm{fb}}(\mathrm{V} v s$. RHE) represents the flat band potential of the $\mathrm{Ta}_{3} \mathrm{~N}_{5}$ electrode. The flat band potential could be derived from the $x$-axis intercept, while the donor density could be obtained from the slope of a Mott-Schottky plot. Electrochemical impedance spectra (EIS) were measured from $100 \mathrm{kHz}$ to $0.1 \mathrm{~Hz}$ using an impedance analyzer under simulated AM 1.5G light in a 0.5 M KPi electrolyte. To alleviate the photocorrosion of $\mathrm{Ta}_{3} \mathrm{~N}_{5}$ photoelectrodes, all the samples were tested in the presence of sacrificial reagent $0.5 \mathrm{M} \mathrm{SO}_{3}{ }^{2-}$ at $1.0 \mathrm{~V} v s$. RHE. The obtained Nyquist plots were fitted from $100 \mathrm{kHz}$ to $1 \mathrm{~Hz}$ with an equivalent circuit model to rule out the fluctuations at frequency lower than $1 \mathrm{~Hz}$.

\section{Results and discussion}

\section{Structure and crystallinity}

A top-view SEM image of a $\mathrm{Ta}_{3} \mathrm{~N}_{5} / \mathrm{NbN}_{x} / \mathrm{Ta} / \mathrm{Ti}$ sample after the thin film transfer is shown in Fig. 2(a). The surface of the $\mathrm{Ta}_{3} \mathrm{~N}_{5}$ film exhibits roughness originating from the porous contact at the $\mathrm{Ta}_{3} \mathrm{~N}_{5} / \mathrm{Si}$ interface in the parent $\mathrm{NbN}_{x} / \mathrm{Ta}_{3} \mathrm{~N}_{5} / \mathrm{Si}$ sample. The possible exposure of the $\mathrm{NbN}_{x}$ interlayer to the film surface is ruled out by the XPS data obtained from the $\mathrm{Ta}_{3} \mathrm{~N}_{5} / \mathrm{NbN}_{x} / \mathrm{Ta} / \mathrm{Ti}$ film, as shown in Fig. S1.† In addition, the absence of Ta species on the surface of the parent $\mathrm{NbN}_{x} / \mathrm{Ta}_{3} \mathrm{~N}_{5} / \mathrm{Si}$ sample suggests that the $\mathrm{Ta}_{3} \mathrm{~N}_{5}$ film was not in direct contact with the underlying metallic substrate. The layered structure of the $\mathrm{Ta}_{3} \mathrm{~N}_{5} / \mathrm{NbN}_{x} / \mathrm{Ta} / \mathrm{Ti}$ sample is clearly observed in the crosssectional SEM image presented in Fig. 2(b). Here, the $\mathrm{NbN}_{x}$ layer is evident as a region of darker contrast, with a thickness of approximately $100 \mathrm{~nm}$. In the magnified view, a porous structure is observed throughout the $\mathrm{Ta}_{3} \mathrm{~N}_{5} / \mathrm{NbN}_{x}$ film, due to the oxidation of the metallic film and the substitution of $\mathrm{O}^{2-}$ ions by $\mathrm{N}^{3-}$ ions during the nitridation process, just as occurs during the nitridation of $\mathrm{Ta}_{2} \mathrm{O}_{5}$ powder to $\mathrm{Ta}_{3} \mathrm{~N}_{5}$. Despite its porous structure, the $\mathrm{NbN}_{x}$ layer is in intimate contact with the
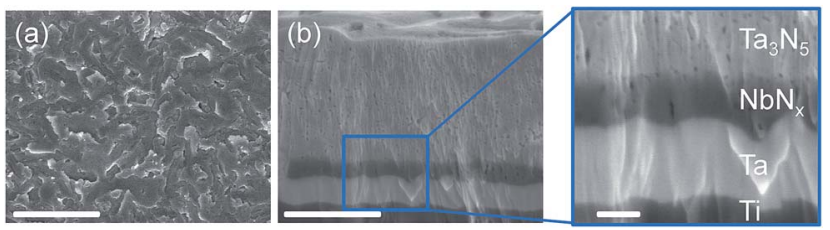

Fig. 2 (a) Top-view and (b) cross-sectional SEM images of a $\mathrm{Ta}_{3} \mathrm{~N}_{5} /$ $\mathrm{NbN}_{x} / \mathrm{Ta} / \mathrm{Ti}$ film. The scale bars are (a) $5 \mu \mathrm{m}$, (b) $500 \mathrm{~nm}$, and $100 \mathrm{~nm}$ for the zoomed image.

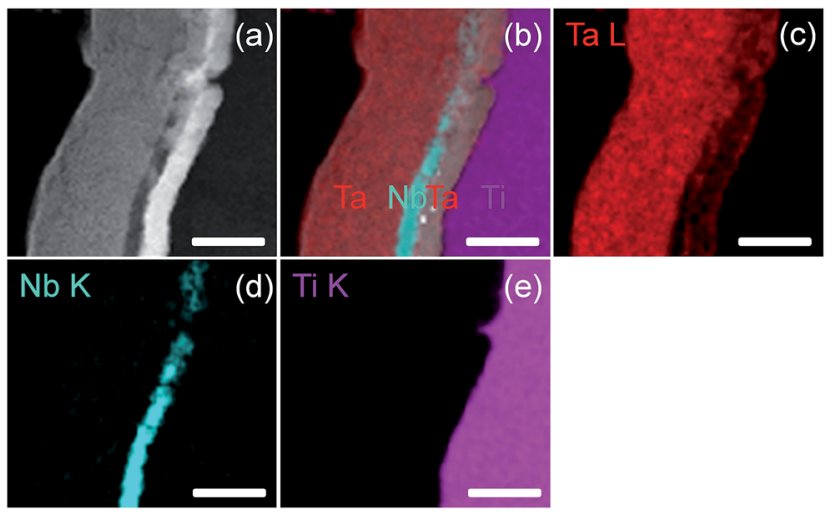

Fig. 3 (a) Cross-sectional STEM image of $\mathrm{TT}_{3} \mathrm{~N}_{5} / \mathrm{NbN}_{x} / \mathrm{Ta} / \mathrm{Ti}$ film and (b)-(e) EDX elemental mappings of the image in (a). All scale bars are $500 \mathrm{~nm}$.

$\mathrm{Ta}_{3} \mathrm{~N}_{5}$ film and the Ta contact layer. The EDX mapping images (Fig. 3) demonstrate that the distribution of $\mathrm{Nb}$ was confined to the interlayer region, so there was no appreciable doping of $\mathrm{Nb}$ into the $\mathrm{Ta}_{3} \mathrm{~N}_{5}$ film.

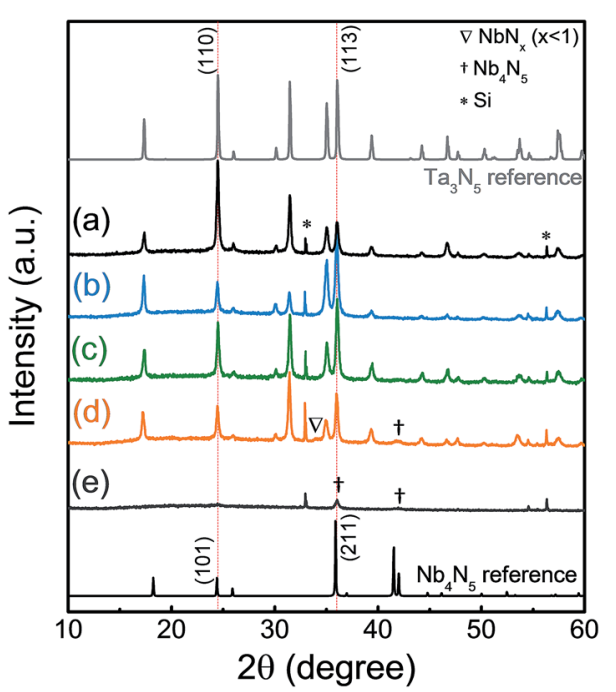

Fig. 4 XRD patterns of (a) $\mathrm{Ta}_{3} \mathrm{~N}_{5} / \mathrm{Si}$, (b) - (d) $\mathrm{NbN}_{x} / \mathrm{Ta}_{3} \mathrm{~N}_{5} / \mathrm{Si}$ with $\mathrm{NbN}_{x}$ thicknesses of (b) 50, (c) 100, and (d) $200 \mathrm{~nm}$, and (e) $\mathrm{NbN}_{x}(100 \mathrm{~nm}) / \mathrm{Si}$ samples. XRD patterns of $\mathrm{Nb}_{4} \mathrm{~N}_{5}$ (PDF\# 74-0606) and $\mathrm{Ta}_{3} \mathrm{~N}_{5}$ (PDF\# 791533) are presented at the bottom and the top, respectively, as references. 
Fig. 4 presents the XRD patterns of $\mathrm{NbN}_{x} / \mathrm{Ta}_{3} \mathrm{~N}_{5} / \mathrm{Si}$ samples with different $\mathrm{NbN}_{x}$ thicknesses prior to the thin film transfer, as a means of confirming the nitridation products. $\mathrm{A} \mathrm{Ta}_{3} \mathrm{~N}_{5}$ phase was evidently formed regardless of whether a $\mathrm{NbN}_{x}$ layer was present or not. In addition, impurity phases such as $\operatorname{TaN}_{x}$ or $\operatorname{SiN}_{x}$ were absent. The diffraction pattern of the $\mathrm{NbN}_{x}$ layer deposited on a $\mathrm{Si}$ substrate (Fig. $4(\mathrm{e})$ ) suggests that $\mathrm{Nb}_{4} \mathrm{~N}_{5}$ was the main phase formed in the $\mathrm{NbN}_{x} / \mathrm{Ta}_{3} \mathrm{~N}_{5} / \mathrm{Si}$ sample, although the crystallinity of this specimen was low, and the diffraction peaks of the (101) and (211) planes of the $\mathrm{Nb}_{4} \mathrm{~N}_{5}$ overlap with those generated by the (110) and (113) planes of the $\mathrm{Ta}_{3} \mathrm{~N}_{5}$ at $24.4^{\circ}$ and $36.0^{\circ}$, respectively. A peak attributable to $\operatorname{NbN}_{x}(x \leq 1)$ was also detected at $34.0^{\circ}$ when the thickness of the $\mathrm{NbN}_{x}$ layer was at its maximum $(200 \mathrm{~nm})$. Nevertheless, the XRD peaks obtained from the $\mathrm{NbN}_{x} /$ $\mathrm{Ta}_{3} \mathrm{~N}_{5} / \mathrm{Si}$ primarily provide information regarding the $\mathrm{Ta}_{3} \mathrm{~N}_{5}$ phase because the $\mathrm{Ta}_{3} \mathrm{~N}_{5}$ peaks are much stronger than those generated by the $\mathrm{Nb}_{4} \mathrm{~N}_{5}$ and other $\mathrm{NbN}_{x}$ phases. It should also be noted that $\mathrm{Nb}_{3} \mathrm{~N}_{5}$ was not observed, as expected because $\mathrm{Nb}^{5+}$ is prone to reduction to $\mathrm{Nb}^{4+}$ or lower-valence nitride species. ${ }^{27}$

The crystallite sizes of the $\mathrm{Ta}_{3} \mathrm{~N}_{5}$ films were calculated from the (110) diffraction peak at $24.4^{\circ}$. The data in Table 1 demonstrate that each of the $\mathrm{Ta}_{3} \mathrm{~N}_{5}$ films had almost identical average crystallite sizes, in the range of 40-45 $\mathrm{nm}$. Thus, the effect of the $\mathrm{NbN}_{x}$ layer on the crystallite size in the $\mathrm{Ta}_{3} \mathrm{~N}_{5}$ film was not significant. Notably, the intensity ratio $\left(R_{\text {in }}\right)$ obtained from the peaks at $24.4^{\circ}$ and $36.0^{\circ}$, which correspond to the (110) and (113) planes of $\mathrm{Ta}_{3} \mathrm{~N}_{5}$, decreased from 2.4 to $0.5-0.8$ when $\mathrm{NbN}_{x}$ layers were present on the $\mathrm{Ta}_{3} \mathrm{~N}_{5}$ films.

The crystalline growth of each $\mathrm{Ta}_{3} \mathrm{~N}_{5}$ film was examined in detail by acquiring cross-sectional TEM images of $\mathrm{Ta}_{3} \mathrm{~N}_{5} / \mathrm{NbN}_{x}$ films (Fig. 5). These bright field (BF) zone-axis TEM images provide a clear view of the multi-layered structure of the $\mathrm{Ta}_{3} \mathrm{~N}_{5}$ /

Table 1 Average crystallite sizes in $\mathrm{Ta}_{3} \mathrm{~N}_{5}$ films with different $\mathrm{NbN}_{x}$ layer thicknesses, as estimated from XRD peaks at $24.4^{\circ}$, as well as the ratios of the (110) and (113) diffraction intensities of the peaks at 24.4 and $36.0^{\circ}$

\begin{tabular}{lll}
\hline $\mathrm{NbN}_{x}$ thickness $(\mathrm{nm})$ & Crystallite size $(\mathrm{nm})$ & Peak intensity ratio \\
\hline 0 & $42.6 \pm 1.8$ & $2.4 \pm 0.2$ \\
50 & $44.3 \pm 1.8$ & $0.5 \pm 0.1$ \\
100 & $41.8 \pm 4.4$ & $0.7 \pm 0.2$ \\
200 & $42.0 \pm 2.7$ & $0.8 \pm 0.1$
\end{tabular}

$\mathrm{NbN}_{x} / \mathrm{Ta}$ samples, and the bright spots scattered within the darker contrast can provide information regarding the sizes and boundaries of individual grains. In Fig. 5(a) and (b), a high density of bright spots is observed throughout the $100 \mathrm{~nm}$-thick $\mathrm{NbN}_{x}$ interlayer, suggesting that the grain size of the $\mathrm{NbN}_{x}$ phase was much less than the layer thickness of $100 \mathrm{~nm}$ (likely below $10 \mathrm{~nm}$ ). This result agrees with the low-crystalline $\mathrm{Nb}_{4} \mathrm{~N}_{5}$ phase indicated by the XRD patterns in Fig. 4. Notably, the $\mathrm{Ta}_{3} \mathrm{~N}_{5}$ region close to the $\mathrm{Ta}_{3} \mathrm{~N}_{5} / \mathrm{NbN}_{x}$ interface generated fewer bright spots when over $200 \mathrm{~nm}$ in thickness, as shown in Fig. 5(c), indicating the presence of fewer boundaries among the $\mathrm{Ta}_{3} \mathrm{~N}_{5}$ grains near the interface with the $\mathrm{NbN}_{x}$ layer, while the rest of the $\mathrm{Ta}_{3} \mathrm{~N}_{5}$ film exhibited a number of bright spots.

Selected area electron diffraction (SAED) patterns taken from the regions at $100 \mathrm{~nm}$ to the film surface and $100 \mathrm{~nm}$ to the $\mathrm{Ta}_{3} \mathrm{~N}_{5} /$ $\mathrm{NbN}_{x}$ interface are displayed in the insets of Fig. 5(b) and (c), respectively. The $\mathrm{Ta}_{3} \mathrm{~N}_{5}$ near the interface with the $\mathrm{NbN}_{x}$ generated a more ordered diffraction pattern compared to the $\mathrm{Ta}_{3} \mathrm{~N}_{5}$ close to the surface, which was characterized by random diffractions. This finding indicates that the arrangement of the $\mathrm{Ta}_{3} \mathrm{~N}_{5}$ grains was well oriented in the vicinity of the $\mathrm{NbN}_{x}$ interlayer. It should be noted that crystallite orientation was not observed at the interface between the $\mathrm{Ta}_{3} \mathrm{~N}_{5}$ film and the $\mathrm{Ta} / \mathrm{Ti}$ substrate of the $\mathrm{Ta}_{3} \mathrm{~N}_{5} / \mathrm{Ta} / \mathrm{Ti}$ film without a $\mathrm{NbN}_{x}$ interlayer, as seen in Fig. S2. $\dagger$

As suggested by the SAED pattern, the formation of a highly oriented $200 \mathrm{~nm} \mathrm{Ta}{ }_{3} \mathrm{~N}_{5}$ layer is not continuous throughout the entirety of the $630 \mathrm{~nm} \mathrm{Ta} \mathrm{N}_{5}$ film. The growth mode of the $\mathrm{Ta}_{3} \mathrm{~N}_{5}$ film in the presence of the $\mathrm{NbN}_{x}$ interlayer appears to be consistent with that observed for $\mathrm{Ta}_{3} \mathrm{~N}_{5}$ films directly grown on Ta foil substrates by thermal nitridation, as reported by Pinaud et $a l .{ }^{18}$ The electrochemically active surface areas (ECSAs) of the $\mathrm{Ta}_{3} \mathrm{~N}_{5}$ films fabricated by Pinaud's group were found to exhibit minimal change up to a film thickness of $260 \mathrm{~nm}$ due to the growth of a compact $\mathrm{Ta}_{3} \mathrm{~N}_{5}$ film. However, the ECSA increased by one or two orders of magnitude when the film thickness was increased from 260 to $630 \mathrm{~nm}$, owing to the growth of disordered layers over top of the compact $\mathrm{Ta}_{3} \mathrm{~N}_{5}$ films. The formation of an oriented $\mathrm{Ta}_{3} \mathrm{~N}_{5}$ layer was also observed in the present $\mathrm{Ta}_{3} \mathrm{~N}_{5}$ films grown on Ta foil substrates (Fig. S3 $\dagger$ ). Therefore, it is believed that both $\mathrm{Ta}_{3} \mathrm{~N}_{5}$ films grown on Ta substrates and films nitrided in contact with a $\mathrm{NbN}_{x}$ interlayer have similar growth mechanisms, presumably involving $\mathrm{Ta}_{4} \mathrm{~N}_{5}$ and $\mathrm{Nb}_{4} \mathrm{~N}_{5}$ with the same crystal structures ${ }^{28,29}$ acting as interlayers, respectively.
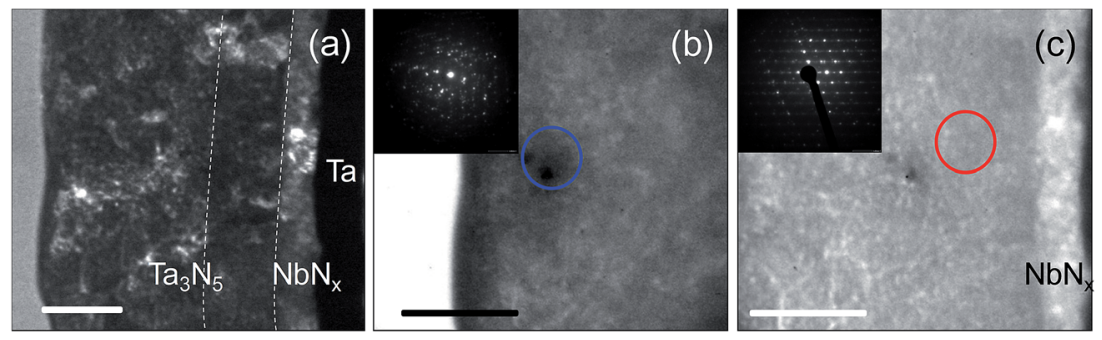

Fig. 5 (a) Zone-axis TEM images of the cross-section of a $\mathrm{Ta}_{3} \mathrm{~N}_{5}$ film on a Ta/Ti substrate with a $\mathrm{NbN}_{x}$ interlayer. The region (200 $\mathrm{nm}$ thick) within the white dashed lines represents the oriented $\mathrm{Ta}_{3} \mathrm{~N}_{5}$ layer. SAED patterns of $\mathrm{Ta}_{3} \mathrm{~N}_{5}$ crystallinites near (b) the surface of the Ta $\mathrm{N}_{5}$ film, and (c) the interface of the $\mathrm{Ta}_{3} \mathrm{~N}_{5} / \mathrm{NbN}_{x}$. The insets are diffraction patterns from the selected regions highlighted by the circles. All scale bars are $200 \mathrm{~nm}$. 


\section{Photoelectrochemical properties}

Current-potential curves obtained from the $\mathrm{Ta}_{3} \mathrm{~N}_{5}$ film photoelectrodes deposited with a layer of $\mathrm{Co}(\mathrm{OH})_{x}$ as an OER catalyst are shown in Fig. 6(a). In the absence of the $\mathrm{NbN}_{x}$ interlayer, the $\mathrm{Ta}_{3} \mathrm{~N}_{5}$ photoelectrode exhibited an anodic photocurrent of approximately $2.0 \mathrm{~mA} \mathrm{~cm}{ }^{-2}$ at $1.23 \mathrm{~V} v s$. RHE. The photocurrent densities increased significantly for the $\mathrm{Ta}_{3} \mathrm{~N}_{5}$ films with $\mathrm{NbN}_{x}$ interlayers 50-100 $\mathrm{nm}$ in thickness. However, the higher resistance of the $\mathrm{NbN}_{x}\left(\mathrm{Nb}_{4} \mathrm{~N}_{5}\right)$ interlayer compared to that of the metallic Ta substrate lowered the electron mobility. As a result, the photocurrent decreased as the thickness of the $\mathrm{NbN}_{x}$ interlayer was increased from 100 to $200 \mathrm{~nm}$. Moreover, the onset potential of the photoanodic current generated by the $\mathrm{Ta}_{3} \mathrm{~N}_{5} / \mathrm{NbN}_{x}(100 \mathrm{~nm}) / \mathrm{Ta} / \mathrm{Ti}$ electrode shifted cathodically by $0.1 \mathrm{~V}$ from $0.9 \mathrm{~V}$ vs. RHE relative to the $\mathrm{Ta}_{3} \mathrm{~N}_{5} / \mathrm{Ta} / \mathrm{Ti}$ electrode. The $\mathrm{NbN}_{x}\left(\mathrm{Nb}_{4} \mathrm{~N}_{5}\right.$ or $\left.\mathrm{NbN}\right)$ phase acts as a conductive contact for the transport of the majority charge carriers (electrons) collected from the $\mathrm{Ta}_{3} \mathrm{~N}_{5}$ film.

To confirm that the enhancement of the photocurrent of $\mathrm{Ta}_{3} \mathrm{~N}_{5} / \mathrm{NbN}_{x}$ photoanodes is associated with the PEC water oxidation performance, gaseous $\mathrm{H}_{2}$ and $\mathrm{O}_{2}$ evolved at the counter electrode and the photoanode at $1.0 \mathrm{~V} v s$. RHE were analyzed using a micro gas chromatograph (Fig. 6(b)). It was confirmed that the amounts of $\mathrm{H}_{2}$ and $\mathrm{O}_{2}$ were virtually equal to the values calculated based on the total charge passed through the system. In addition, the ratio of $\mathrm{H}_{2}$ to $\mathrm{O}_{2}$ was close to $2: 1$. These results indicate that the faradaic efficiency during the OER process was unity when employing the $\mathrm{Ta}_{3} \mathrm{~N}_{5} / \mathrm{NbN}_{x}$ photoanode. However, the gas evolution rates decreased in accordance with changes in the photocurrent over time, as can be seen in Fig. 6(c). The decreased photocurrent and $\mathrm{O}_{2}$ evolution rate likely resulted from dissolution of the Co-based catalysts from the surface of the $\mathrm{Ta}_{3} \mathrm{~N}_{5}$ film into the electrolyte solution. ${ }^{30}$ The loss of the Co-based catalyst led to direct exposure of the $\mathrm{Ta}_{3} \mathrm{~N}_{5}$ film to the electrolyte solution, and consequently to gradual degradation of the photoanode because bare $\mathrm{Ta}_{3} \mathrm{~N}_{5}$ photoanodes are prone to photocorrosion. ${ }^{31} \mathrm{~A}$ uniform coverage of the $\mathrm{Ta}_{3} \mathrm{~N}_{5}$ electrode with protective and catalytic layers is likely to stabilize the photocurrent. In addition, the Co-based catalyst can be replaced by other oxygen-evolution catalysts (e.g. $\mathrm{NiO}_{x}$ ), which are electrochemically stable against the dissolution under alkaline conditions.

The IPCE spectra shown in Fig. 7 are consistent with the increases in photocurrent densities brought about by the $\mathrm{NbN}_{x}$ interlayers (see Fig. 6(a)). The onset of a photoresponse at 600 $\mathrm{nm}$ corresponds to the direct band gap of $\mathrm{Ta}_{3} \mathrm{~N}_{5}$ at $2.1 \mathrm{eV}$. It should be noted that a shoulder is observed at $500 \mathrm{~nm}$ in each of the IPCE plots. This is also ascribed to the direct transition of $\mathrm{Ta}_{3} \mathrm{~N}_{5}$ between the $\mathrm{N} 2 \mathrm{p}$ and Ta $5 \mathrm{~d}$ states, as was suggested by earlier optical and theoretical studies of $\mathrm{Ta}_{3} \mathrm{~N}_{5}$ films. ${ }^{17,32}$ The IPCEs of $\mathrm{Ta}_{3} \mathrm{~N}_{5} / \mathrm{NbN}_{x}$ photoelectrodes at $400-550 \mathrm{~nm}$ were evidently increased compared to the bare $\mathrm{Ta}_{3} \mathrm{~N}_{5}$ photoelectrode. Because less than $5 \%$ of light can traverse through the $\mathrm{Ta}_{3} \mathrm{~N}_{5}$ film to the $\mathrm{NbN}_{x}$ interlayer below $550 \mathrm{~nm}$ (see Fig. S4 $\dagger$ ), it is unlikely that the photoresponse of the $\mathrm{Ta}_{3} \mathrm{~N}_{5} / \mathrm{NbN}_{x}$ electrode was affected by the light absorption characteristics of the $\mathrm{NbN}_{x}$ interlayer and the $\mathrm{Ta}_{3} \mathrm{~N}_{5} / \mathrm{NbN}_{x}$ interface. Therefore, it is thought that the enhancements in the IPCE and the photocurrent density of the $\mathrm{Ta}_{3} \mathrm{~N}_{5} / \mathrm{NbN}_{x}$ photoelectrodes are primarily due to the changes in the structural features of the $\mathrm{Ta}_{3} \mathrm{~N}_{5}$ film induced by the $\mathrm{NbN}_{x}$ interlayer.

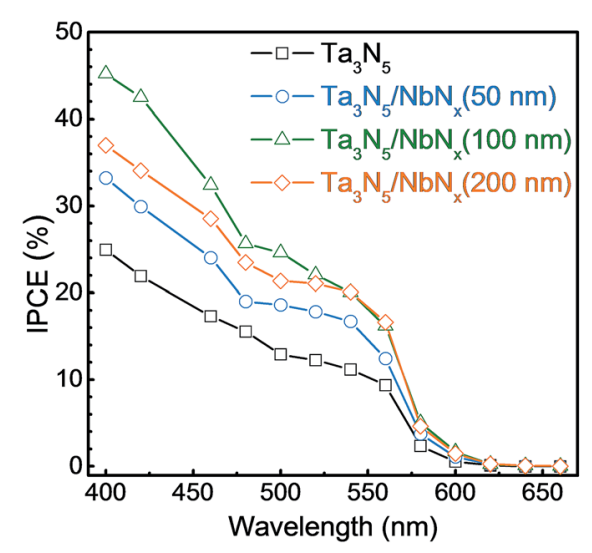

Fig. 7 IPCE spectra of $\mathrm{Ta}_{3} \mathrm{~N}_{5} / \mathrm{Ta} / \mathrm{Ti}$ and $\mathrm{Ta}_{3} \mathrm{~N}_{5} / \mathrm{NbN}_{x} / \mathrm{Ta} / \mathrm{Ti}$ photoelectrodes with different $\mathrm{NbN}_{x}$ interlayer thicknesses.
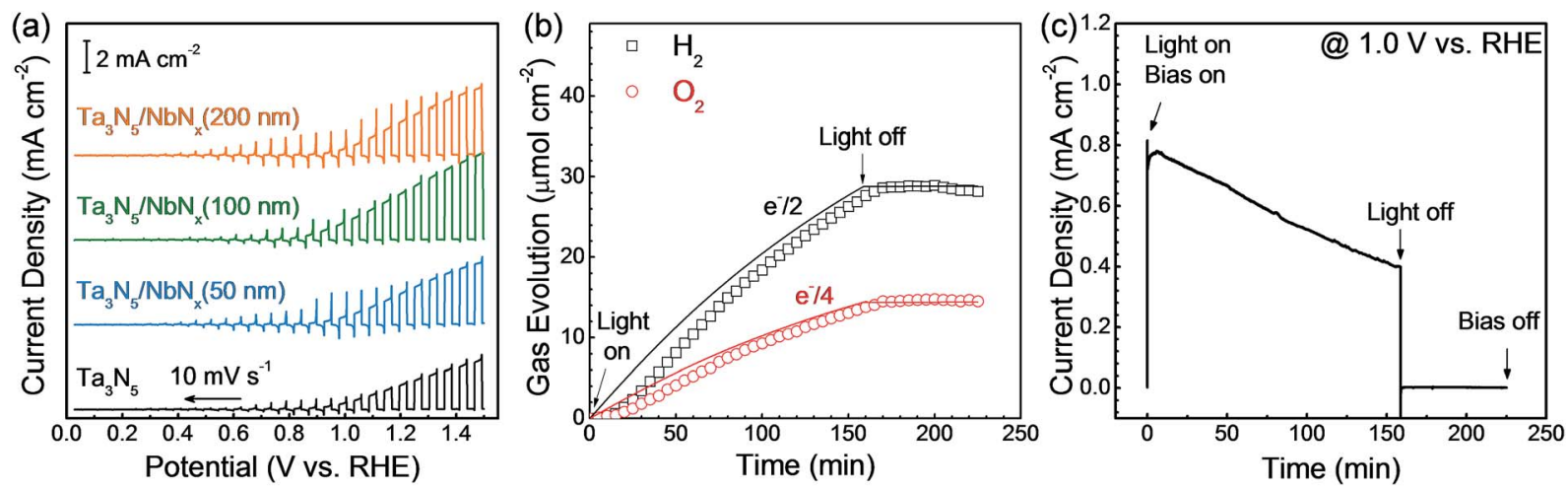

Fig. 6 (a) Current-potential curves obtained from $\mathrm{Ta}_{3} \mathrm{~N}_{5} / \mathrm{Ta} / \mathrm{Ti}$ and $\mathrm{Ta}_{3} \mathrm{~N}_{5} / \mathrm{NbN}_{x} / \mathrm{Ta} / \mathrm{Ti}$ photoelectrodes with different $\mathrm{NbN} \mathrm{N}_{x}$ interlayer thicknesses, (b) hydrogen and oxygen gas evolution with respect to the total charge passed, as calculated from the (c) current-time curve obtained from the $\mathrm{Co}(\mathrm{OH})_{x} / \mathrm{Ta}_{3} \mathrm{~N}_{5} / \mathrm{NbN}_{x}(100 \mathrm{~nm}) / \mathrm{Ta} / \mathrm{Ti}$ photoelectrode held at $1.0 \mathrm{~V}$ vs. RHE. The PEC activities and gas evolution were assessed in a $0.5 \mathrm{M}$ potassium phosphate solution $(\mathrm{pH} 13)$ under simulated $\mathrm{AM} 1.5 \mathrm{G}$ light. 


\section{Charge separation and transport}

In the PEC water oxidation process, light harvesting, charge separation and transport, and hole injection are the three key processes that define the PEC activity and IPCE. The light harvesting of the $\mathrm{Ta}_{3} \mathrm{~N}_{5}$ films would not be expected to have been altered by the $\mathrm{NbN}_{x}$ interlayers because the film thickness and crystallite size were unchanged. It is also believed that the hole injection process was not affected by the presence of the interlayer because of the similarities in the roughness factors, flat band potentials, and donor densities. ECSA values were estimated from the double-layer charging in the cyclic voltammograms (CVs) as a means of examining the surface roughness of the $\mathrm{Ta}_{3} \mathrm{~N}_{5}$ electrodes (Fig. $\mathrm{S} 5 \dagger$ ), and the roughness factor was found to be barely changed by the presence of the $\mathrm{NbN}_{x}$ interlayer. Mott-Schottky plots (Fig. S6†) were used to estimate the flat band potentials and the carrier densities, with values of -0.06 and $-0.08 \mathrm{~V}$ vs. RHE, respectively. Hence, charge separation and transport are evidently the major factors contributing to the enhancement of the photocurrent by the $\mathrm{NbN}_{x}$ interlayer. Electrochemical impedance spectra (EIS) of $\mathrm{Ta}_{3} \mathrm{~N}_{5}$ and $\mathrm{Ta}_{3} \mathrm{~N}_{5} / \mathrm{NbN}_{x}$ electrodes are shown in Fig. 8. The Nyquist plots with a feature of single capacitance were fitted using the Randles equivalent circuit model, similar to the case for hematite photoanodes in the presence of $\left[\mathrm{Fe}(\mathrm{CN})_{6}\right]^{3-/ 4-}$ redox couples. ${ }^{33}$ This equivalent circuit consists of the series resistance $\left(R_{\mathrm{S}}\right)$ of the $\mathrm{NbN}_{x}$ and $\mathrm{Ta} / \mathrm{Ti}$ layers, the capacitance of the bulk $\mathrm{Ta}_{3} \mathrm{~N}_{5}$ film (CPE), and the charge transfer resistance from the valence band of $\mathrm{Ta}_{3} \mathrm{~N}_{5}$ to the solution $\left(R_{\mathrm{CT}}\right)$, which may be associated with resistances representing bulk recombination and charge transfer at the electrolyte/semiconductor interface. The values of the charge transfer resistance $\left(R_{\mathrm{CT}}\right.$, Table $\left.\mathrm{S} 1 \dagger\right)$ of all the $\mathrm{Ta}_{3} \mathrm{~N}_{5} / \mathrm{NbN}_{x}$ photoelectrodes were smaller than that of the unmodified $\mathrm{Ta}_{3} \mathrm{~N}_{5}$ photoelectrode although the surface reaction was the same, oxidation of sulfite ions on the $\mathrm{Ta}_{3} \mathrm{~N}_{5}$ surface. This result suggests an increase in the population of holes that survive recombination with electrons and

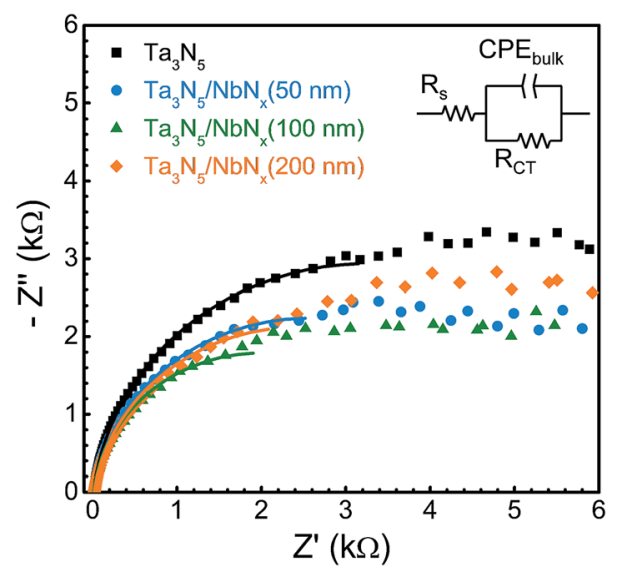

Fig. 8 Nyquist plots of electrochemical impedance spectra of $\mathrm{Ta}_{3} \mathrm{~N}_{5}$ and $\mathrm{Ta}_{3} \mathrm{~N}_{5} / \mathrm{NbN}_{x}$ electrodes measured under simulated AM 1.5G light in a $0.5 \mathrm{M} \mathrm{KPi}$ solution ( $\mathrm{pH}$ 13) with a sacrificial reagent $\left(0.5 \mathrm{M} \mathrm{SO}_{3}{ }^{2-}\right)$ at $1.0 \mathrm{~V}$ vs. RHE. The inset represents the Randles equivalent circuit used for fitting the Nyquist plots. successfully reach the semiconductor/liquid junction as a result of promotion of charge separation and transport process by the $\mathrm{NbN}_{x}$ interlayers. The $R_{\mathrm{s}}$ increased with the thickness of the $\mathrm{NbN}_{x}$ layer because of its lower conductivity. However, the contribution of $R_{\mathrm{s}}$ to the total resistance is negligible.

Two charge generation and transport scenarios can be considered, depending on whether photons are absorbed near the $\mathrm{Ta}_{3} \mathrm{~N}_{5}$ film surface (case i) or the $\mathrm{Ta}_{3} \mathrm{~N}_{5} / \mathrm{NbN}_{x}$ interface (case ii), as depicted in Fig. 9. Long-distance electron transport and shortdistance hole transport occur in the former case (i) while longdistance hole transport and short-distance electron transport take place in the latter case (ii). The analysis of the integrated photocurrent calculated on the basis of the standard AM 1.5G (ASTM G173-03) spectrum and the IPCE spectra (Fig. S7 $\dagger$ ) indicates that the short-wavelength light absorbed near the $\mathrm{Ta}_{3} \mathrm{~N}_{5} / \mathrm{NbN}_{x}$ electrode surface showed a larger contribution to the enhancement in photocurrent than the long-wavelength light absorbed near the $\mathrm{Ta}_{3} \mathrm{~N}_{5} / \mathrm{NbN}_{x}$ interface. The formation of an oriented $\mathrm{Ta}_{3} \mathrm{~N}_{5}$ layer (200 nm thick) by the $\mathrm{NbN}_{x}$ interlayer probably promotes the electron mobility in the $\mathrm{Ta}_{3} \mathrm{~N}_{5}$ film near the $\mathrm{Ta}_{3} \mathrm{~N}_{5} / \mathrm{NbN}_{x}$ interface. Therefore, photogenerated charges near the surface may contribute to the PEC water oxidation more effectively in the presence of a $\mathrm{NbN}_{x}$ interlayer, given that the migration distance required for holes to reach the surface is shorter in a disordered $\mathrm{Ta}_{3} \mathrm{~N}_{5}$ layer. Nevertheless, it should be pointed out that the photons absorbed near the $\mathrm{Ta}_{3} \mathrm{~N}_{5} / \mathrm{NbN}_{x}$ interface are not necessarily utilized efficiently even in the presence of a $\mathrm{NbN}_{x}$ interlayer because holes generated deeper in the $\mathrm{Ta}_{3} \mathrm{~N}_{5}$ film have a higher probability of recombining with electrons before reaching the surface, since the hole mobility is lower than the electron mobility. ${ }^{17}$ As a consequence, the photocurrent observed in the present study was still lower than the maximum theoretical value for $\mathrm{Ta}_{3} \mathrm{~N}_{5}$, so it is most likely necessary to tune the thicknesses of the oriented and disordered $\mathrm{Ta}_{3} \mathrm{~N}_{5}$ layers.

A photoanode configuration consisting of a lower oriented $\mathrm{Ta}_{3} \mathrm{~N}_{5}$ layer and an upper disordered $\mathrm{Ta}_{3} \mathrm{~N}_{5}$ layer represents a combination of a short migration distance for photoexcited holes and efficient electron transport toward the back conductor layer. The introduction of the $\mathrm{NbN}_{x}$ interlayer effectively realizes this ideal photoanode configuration and thus enhances the PEC performance. This result suggests that the structural and PEC properties of $\mathrm{Ta}_{3} \mathrm{~N}_{5}$ photoanodes can be improved by designing appropriate interlayers, regardless of the nitridation of the $\mathrm{Ta}_{3} \mathrm{~N}_{5}$ film and the particular back conductor material employed. The

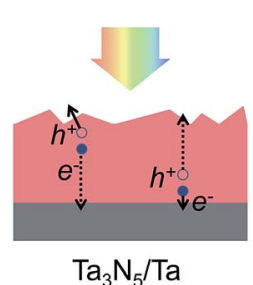

(a)

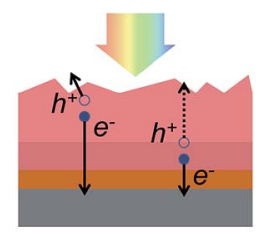

$\mathrm{Ta}_{3} \mathrm{~N}_{5} / \mathrm{Nb}_{4} \mathrm{~N}_{5} / \mathrm{Ta}$

(b)
Fig. 9 Schematic depicting the separation and transport of photogenerated electrons and holes in (a) $\mathrm{Ta}_{3} \mathrm{~N}_{5} / \mathrm{Ta}$ and (b) $\mathrm{Ta}_{3} \mathrm{~N}_{5} / \mathrm{NbN}_{x} / \mathrm{Ta}$ films. 
film transfer method developed in this study presents a means of studying such aspects owing to the controllability of the thickness and the stacking order of multilayers.

\section{Conclusions}

$\mathrm{NbN}_{x}$ layers principally consisting of $\mathrm{Nb}_{4} \mathrm{~N}_{5}$ were introduced as interlayers between $\mathrm{Ta}_{3} \mathrm{~N}_{5}$ films and the back substrate, using the film transfer method. The $\mathrm{Nb}_{4} \mathrm{~N}_{5}$ interlayer did not change the phase purities and the crystallite sizes of the $\mathrm{Ta}_{3} \mathrm{~N}_{5}$ films significantly, although the preference in the crystalline orientation of the $\mathrm{Ta}_{3} \mathrm{~N}_{5}$ film was enhanced by the $\mathrm{Nb}_{4} \mathrm{~N}_{5}$ phase. The photocurrents obtained from $\mathrm{Ta}_{3} \mathrm{~N}_{5}$ photoanodes during the PEC water oxidation reaction increased significantly in the presence of the $\mathrm{NbN}_{x}$ interlayer. The results of zone-axis imaging and electron diffraction from cross-sectional TEM revealed that ordered growth of the $\mathrm{Ta}_{3} \mathrm{~N}_{5}$ film occurred and that a $200 \mathrm{~nm}$ layer of highly grain-oriented $\mathrm{Ta}_{3} \mathrm{~N}_{5}$ was formed near the $\mathrm{Ta}_{3} \mathrm{~N}_{5} / \mathrm{NbN}_{x}$ interface. The formation of an oriented $\mathrm{Ta}_{3} \mathrm{~N}_{5}$ layer did not affect the ECSA, flat band potential or carrier density of a $630 \mathrm{~nm} \mathrm{Ta} \mathrm{N}_{5}$ film. The increased photocurrent associated with the presence of a $\mathrm{NbN}_{x}$ interlayer is primarily attributed to the increased long distance electron mobility in the $\mathrm{Ta}_{3} \mathrm{~N}_{5}$ film. The film growth on the $\mathrm{Nb}_{4} \mathrm{~N}_{5}$ layer observed in this work demonstrates the key roles of a buffer layer in the design and synthesis of efficient $\mathrm{Ta}_{3} \mathrm{~N}_{5}$ photoelectrodes.

\section{Acknowledgements}

This work was financially supported by Grants-in-Aid for Specially Promoted Research (No. 23000009) and for Young Scientists (A) (No. 15H05494) and Young Scientists (B) (No. 5K17895) of Japan Society for the Promotion of Science (JSPS). This work was partly supported by the Artificial Photosynthesis Project of the New Energy and Industrial Technology Development Organization (NEDO) and Companhia Brasileira de Metalurgia e Mineração (CBMM). Part of this work was conducted at the Research Hub for Advanced Nano Characterization at the University of Tokyo, under the support of the "Nanotechnology Platform" (project No. 12024046) of the Ministry of Education, Culture, Sports, Science and Technology (MEXT), Japan. The authors thank Dr Qian Wang, Dr Miao Zhong, Dr Taro Yamada and Mr Yutaka Sasaki of the University of Tokyo for SEM characterisation and discussion.

\section{References}

1 A. J. Nozik, Annu. Rev. Phys. Chem., 1978, 29, 189-222.

2 M. Grätzel, Nature, 2001, 414, 338-344.

3 A. Fujishima and K. Honda, Nature, 1972, 238, 37-38.

4 W. J. Chun, A. Ishikawa, H. Fujisawa, T. Takata, J. N. Kondo, M. Hara, M. Kawai, Y. Matsumoto and K. Domen, J. Phys. Chem. B, 2003, 107, 1798-1803.

5 T. W. Kim and K.-S. Choi, Science, 2014, 343, 990-994.

6 Y. Li, T. Takata, D. Cha, K. Takanabe, T. Minegishi, J. Kubota and K. Domen, Adv. Mater., 2013, 25, 125-131.
7 M. Zhong, Y. Ma, P. Oleynikov, K. Domen and J.-J. Delaunay, Energy Environ. Sci., 2014, 7, 1693-1699.

8 H. X. Dang, N. T. Hahn, H. S. Park, A. J. Bard and C. B. Mullins, J. Phys. Chem. C, 2012, 116, 19225-19232.

9 T. Minegishi, N. Nishimura, J. Kubota and K. Domen, Chem. Sci., 2013, 4, 1120-1124.

10 K. Ueda, T. Minegishi, J. Clune, M. Nakabayashi, T. Hisatomi, H. Nishiyama, M. Katayama, N. Shibata, J. Kubota, T. Yamada and K. Domen, J. Am. Chem. Soc., 2015, 137, 2227-2230.

11 Y. Li, L. Zhang, A. Torres-Pardo, J. M. Gonzalez-Calbet, Y. Ma, P. Oleynikov, O. Terasaki, S. Asahina, M. Shima, D. Cha, L. Zhao, K. Takanabe, J. Kubota and K. Domen, Nat. Commun., 2013, 4, 2566.

$12 \mathrm{~S} . \mathrm{Hu}, \mathrm{M} . \mathrm{R}$. Shaner, J. A. Beardslee, M. Lichterman, B. S. Brunschwig and N. S. Lewis, Science, 2014, 344, 10051009.

13 L. Chen, J. Yang, S. Klaus, L. J. Lee, R. Woods-Robinson, J. Ma, Y. Lum, J. K. Cooper, F. M. Toma, L. W. Wang, I. D. Sharp, A. T. Bell and J. W. Ager, J. Am. Chem. Soc., 2015, 137, 9595-9603.

14 G. Liu, J. Shi, F. Zhang, Z. Chen, J. Han, C. Ding, S. Chen, Z. Wang, H. Han and C. Li, Angew. Chem., Int. Ed., 2014, 53, 7295-7299.

15 G. Liu, P. Fu, L. Zhou, P. Yan, C. Ding, J. Shi and C. Li, Chem.-Eur. J., 2015, 21, 9624-9628.

16 J. Seo, T. Takata, M. Nakabayashi, T. Hisatomi, N. Shibata, T. Minegishi and K. Domen, J. Am. Chem. Soc., 2015, 137, 12780-12783.

17 J. M. Morbec, I. Narkeviciute, T. F. Jaramillo and G. Galli, Phys. Rev. B, 2014, 90, 155204.

18 B. A. Pinaud, P. C. K. Vesborg and T. F. Jaramillo, J. Phys. Chem. C, 2012, 116, 15918-15924.

19 M. X. Li, W. J. Luo, D. P. Cao, X. Zhao, Z. S. Li, T. Yu and Z. G. Zou, Angew. Chem., Int. Ed., 2013, 52, 11016-11020.

20 B. A. Pinaud, A. Vailionis and T. F. Jaramillo, Chem. Mater., 2014, 26, 1576-1582.

21 S. Nakamura, Jpn. J. Appl. Phys., 1991, 30, 1705-1707.

22 F. A. Ponce and D. P. Bour, Nature, 1997, 386, 351-359.

23 A. Dabirian and R. van de Krol, Chem. Mater., 2015, 27, 708-715.

24 G. Liu, S. Ye, P. Yan, F. Xiong, P. Fu, Z. Wang, Z. Chen, J. Shi and C. Li, Energy Environ. Sci., 2016, 9, 1327-1334.

25 C. Wang, T. Hisatomi, T. Minegishi, M. Nakabayashi, N. Shibata, M. Katayama and K. Domen, Chem. Sci., 2016, 7, 5821-5826.

26 C. C. L. McCrory, S. Jung, J. C. Peters and T. F. Jaramillo, J. Am. Chem. Soc., 2013, 135, 16977-16987.

27 R. Fix, R. G. Gordon and D. M. Hoffman, Chem. Mater., 1993, 5, 614-619.

28 T. Nobuzo, Jpn. J. Appl. Phys., 1971, 10, 248-259.

29 G. Oya and Y. Onodera, J. Appl. Phys., 1974, 45, 1389-1397.

30 G. M. Carroll, D. K. Zhong and D. R. Gamelin, Energy Environ. Sci., 2015, 8, 577-584.

31 S. Chen and L.-W. Wang, Chem. Mater., 2012, 24, 3659-3666. 32 A. H. Reshak, Comput. Mater. Sci., 2014, 89, 45-51.

33 B. Klahr, S. Gimenez, F. Fabregat-Santiago, J. Bisquert and T. W. Hamann, Energy Environ. Sci., 2012, 5, 7626-7636. 